PEMBELAJAR: Jurnal Ilmu Pendidikan, Keguruan, dan Pembelajaran

Volume 2 Nomor 2 Oktober 2018

e-ISSN: 2549-9114 dan p-ISSN: 2549-9203

(Received: Agustus 2018; Reviewed: September-2018; Published: Oktober 2018)

DOI: http://dx.doi.org/10.26858/pembelajar.v2i2.7098

\title{
Meningkatkan Hasil Belajar IPA Siswa Kelas IV-B melalui Pemanfaatan Media Audio-Visual (Film Projector) SD Negeri Kompleks IKIP 1 Kota Makassar
}

\author{
Alphian Sahruddin \\ SD Negeri Kompleks IKIP I Makassar \\ Email: phianshof86@gmail.com
}

\begin{abstract}
Abstrak : Penelitian ini bertujuan untuk meningkatkan hasil belajar IPA dengan pemanfaatan media Audio-Visual (Film Projector). Subjek penelitian berjumlah 45 siswa kelas IV-B semester Ganjil SD Negeri Kompleks IKIP 1 Kota Makassar tahun pelajaran 2015/2016. Penelitian berlangsung selama 3 bulan terdiri atas dua siklus. Hasil penelitian menunjukkan bahwa pemanfaatan media Audio-Visual (Film Projector) dapat meningkatkan hasil belajar IPA. Nilai rerata IPA meningkat, dari siklus pertama mencapai skor 69,93 kemudian meningkat menjadi skor 81,84 pada siklus kedua. Ketuntasan belajar secara klasikal meningkat dari $58 \%$ menjadi $91 \%$. Dengan demikian ada manfaat positif atas tindakan yang dilakukan guru berupa penggunaan media Audio-Visual (Film Projector).
\end{abstract}

Kata Kunci : Hasil Belajar, IPA, Media Audio-Visual (Film Projector)

\begin{abstract}
This research aims to improve science learning outcomes with the use of media Audio-Visual (Film Projector). The research subjects were 40 students of class IV-B half of Odd Elementary SD Negeri Kompleks IKIP 1 of Makassar in the academic year 2015/2016. Three-mounts study consisted of two cycles. The results showed that the use of media Audio-Visual (Film Projector) can improve science learning outcomes. Increased average value of science, from the first cycle reaches a score of 69,93 and then increased to a score of 81,84 in the second cycle. Classical learning completeness increased from $58 \%$ to $91 \%$. Thus there are positive benefits for the actions of teachers in the form of media use Audio-Visual (Film Projector).
\end{abstract}

Keywords : Results Learning, Science, Audio-Visual Media (Film Projector)

C2018 -Pembelajar Universitas Negeri Makassar. Ini adalah artikel dengan akses terbuka dibawah licenci CC BY-NC-4.0 (https://creativecommons.org/licenses/by-nc/4.0/ ).

\section{PENDAHULUAN}

Manusia sebagai makhluk sosial membutuhkan pendidikan guna menjawab tantangan zaman serta kemajuan teknologi yang semakin pesat. Untuk dapat membekali diri dengan berbagai macam keterampilan dasar, dibutuhkan lembaga pendidikan formal yaitu Sekolah Dasar. Pendidikan di sekolah dasar diselenggarakan untuk mengembangkan sikap, kemampuan, pengetahuan dan keterampilan dasar yang diperlukan guna mempersiapkan diri mengikuti pendidikan selanjutnya.
Sehubungan dengan hal tersebut di atas, untuk melaksanakan pendidikan di sekolah dasar diperlukan pengajaran dari berbagai disiplin ilmu, salah satu disiplin ilmu itu adalah IPA. Darmodjo (1992) mengemukakan bahwa "IPA sangat diperlukan oleh siswa sekolah dasar, karena pembelajaran IPA dapat memberikan masukan bagi pencapaian pendidikan dasar selanjutnya".

SD Negeri Kompleks IKIP 1 Makassar merupakan sekolah yang masih menerapkan KTSP. Berada di Pusat Kota Makassar, tuntutan perbaikan kualitas pembelajaran menjadi hal 
yang wajib. Visi sekolah adalah "Mewujudkan Peserta Didik Yang Beriman, Cerdas, Terampil, Berkarakter, dan Peduli Lingkungan”. Salah satu Misi untuk mencapai Visi tersebut adalah "meningkatkan kualitas pembelajaran aktif, inovatif, kreatif, dan menyenangkan" (RKAS, 2015). Kemampuan peserta didik yang beragam menuntut guru harus menguasai berbagai model dan metode pembelajaran serta mempunyai kemampuan menggunakan berbagai Media Pembelajaran Inovatif yang menyenangkan bagi siswa. Namun kenyataannya setelah melakukan Ulangan Harian pada pelajaran IPA, beberapa siswa kelas IV-B memperoleh hasil belajar yang tinggi, namun masih banyak siswa yang memperoleh hasil belajar yang rendah. Hal ini terbukti dari rendahnya persentase siswa yang mencapai batas Kriteria Ketuntasan Minimal (KKM) yaitu 70. Dari 45 siswa hanya $21(46,67 \%)$ siswa saja yang mencapai KKM. Berikut adalah hasil belajar siswa.

Tabel 1 : Data Nilai Siswa Pelajaran IPA

\begin{tabular}{ccccc}
\hline No & Interval & F & $(\%)$ & Rerata \\
\hline $\mathbf{1}$ & $0-59$ & 12 & 26,67 & \\
$\mathbf{2}$ & $60-69$ & 12 & 26,67 & \\
$\mathbf{3}$ & $70-79$ & 8 & 17,78 & 66,38 \\
$\mathbf{4}$ & $80-89$ & 13 & 28,89 & \\
$\mathbf{5}$ & $90-100$ & 0 & 0 & \\
\hline & Total & $\mathbf{4 5}$ & $\mathbf{1 0 0}$ & \\
\hline
\end{tabular}

Perkembangan ilmu pengetahuan dan teknologi telah membawa perubahan yang signifikan terhadap berbagai dimensi kehidupan manusia, baik dalam ekonomi, sosial, budaya, maupun pendidikan. Oleh karena itu, agar pendidikan tidak tertinggal dari perkembangan IPTEK tersebut perlu adanya penyesuaianpenyesuaian, terutama sekali yang berkaitan dengan faktor-faktor pengajaran di sekolah. Salah satu faktor tersebut adalah media pembelajaran yang perlu dikuasai oleh guru maupun calon guru khususnya media elektronika dalam proses belajar mengajar, sehingga dalam menyampaikan pesan pembelajaran dapat berlangsung dengan baik, berdaya guna, dan berhasil guna sehingga mampu meningkatkan minat dan hasil belajar siswa. Hal ini sejalan dengan pendapat Asnawir dan Usman (2002:11) yang mengemukakan bahwa media merupakan sesuatu yang bersifat menyalurkan pesan dan dapat merangsang pikiran, perasaan, dan kemauan audien (siswa) sehingga dapat mendorong terjadinya proses belajar pada dirinya.

Seorang Insinyur dari Amerika B. Fuller (Depdiknas, 2003) mengatakan bahwa media telah menjadi "Orang Tua Ketiga" bagi anak setelah guru sebagai orang tua kedua. Hal ini memperlihatkan bahwa media telah menunjukkan keunggulannya membantu para guru dan staf pengajar dalam menyampaikan pesan pembelajaran serta lebih cepat dan lebih mudah ditangkap oleh siswa. Sehubungan dengan hal itu, peran media sangat dibutuhkan dalam pembelajaran dimana dalam perkembangannya saat ini media bukan lagi dipandang sekedar alat bantu tetapi merupakan bagian integral dalam sistem pendidikan dan pembelajaran.

Salah satu upaya yang disepakati dalam mengatasi masalah di atas adalah dengan pemanfaatan media Audio-Visual (Film Projector) sebagai media pembelajaran, sehingga siswa tertarik dalam pembelajaran IPA. Melalui penggunaan media Audio-Visual (Film Projector) dalam pembelajaran IPA di sekolah dasar, diharapkan dapat meningkatkan hasil belajar siswa, sebagaimana karakteristik siswa sekolah dasar (Slameto, 2003:81) sangat tertarik terhadap sesuatu hal yang diamati, didengar dan dialaminya secara langsung, karena dapat menimbulkan kesan bermakna dalam diri individu siswa.

Menurut Arsyad (2009:30) pengajaran melalui Audio-Visual adalah produksi dan penggunaan materi yang penyerapannya melalui pendengaran dan pandangan serta tidak seluruhnya tergantung kepada pemahaman kata atau simbol-simbol yang serupa. Pemahaman yang dipakai melalui Audio-Visual merupakan cara yang tepat digunakan di kelas, karena penggunaan media ini memecahkan aspek verbalisme pada diri siswa. Contohnya pada awal pembelajaran, siswa diterangkan mengenai invertebrata, setelah itu guru memperlihatkan gambar cacing, ubur-ubur, dan lainnya. Selanjutnya akan dipertontonkan film mengenai materi tersebut akhirnya siswa menjadi paham.

Terkait dengan latar belakang di atas rumusan masalah yang hendak dicari penyelesaiannya dalam penelitian ini adalah bagaimanakah efektivitas pemanfaatan media Audio-Visual (Film Projector)?, sedangkan Permasalahan tersebut dibatasi lingkup pembahasannya pada dua hal, yaitu 1) Bagaimanakah pemanfaatan Media Audio-Visual 
(Film Projector) dalam meningkatkan hasil belajar IPA siswa kelas IV-B SD Negeri Kompleks IKIP 1 Makassar? 2) Apakah hasil belajar IPA dapat ditingkatkan melalui pemanfaatan media Audio-Visual (Film Projector) siswa Kelas IV-B SD Negeri Kompleks IKIP 1 Makassar?

Manfaat yang diharapkan dalam penelitian ini secara teoritis 1) bagi lembaga pendidikan menjadi bahan informasi dalam pengembangan ilmu pengetahuan khususnya pembelajaran IPA di SD; 2) bagi peneliti lain, dapat dijadikan sebagai referensi/perbandingan.

Sedangkan secara praktis bagi siswa, penelitian ini bermanfaat untuk meningkatkan hasil belajar siswa pada pelajaran IPA; 2) mengatasi kesulitan siswa dalam pembelajaran IPA.

Bagi guru penelitian ini bermanfaat agar 1) guru dapat memilih model pembelajaran yang tepat untuk dilaksanakan; 2) kemampuan guru dalam mengelola pembelajaran IPA meningkat sehingga hasil belajar siswa lebih baik. Sedangkan bagi sekolah penelitian ini bermanfaat untuk memberikan sumbangan yang positif terhadap kinerja guru sehingga kualitas pembelajaran di sekolah meningkat.

\section{KAJIAN PUSTAKA}

\subsection{Pembelajaran IPA}

Beberapa ahli menyatakan bahwa pengertian Ilmu Pengetahuan Alam sering disingkat dengan kata IPA atau yang saat ini sering kita dengar dengan istilah Sains. IPA merupakan pelajaran wajib di sekolah dasar. Dengan belajar IPA siswa dapat mempelajari diri sendiri dan alam sekitar. Pendidikan IPA menekankan pada pemberian pemahaman langsung dan kegiatan praktis untuk mengembangkan kompetensi agar siswa mampu memahami alam sekitar secara alamiah. Dalam hal ini IPA dapat melatih anak dapat berfikir kritis dan objektif (Samatowa, 2010: 4).

Ilmu Pengetahuan Alam (IPA) merupakan bagian dari ilmu pengetahuan atau Sains yang semula berasal dari bahasa Inggris "Science" sendiri berasal dari kata dalam bahasa Latin "Scientia" yang berarti saya tahu (Trianto, 2010:136).

Pengertian IPA menurut Maslichah (2006:7) Sains adalah pengetahuan manusia tentang alam yang diperoleh dengan cara yang terkontrol. Penjelasan ini mengandung maksud bahwa sains selain menjadi sebagai produk juga sebagai proses. Sains sebagai produk yaitu pengetahuan manusia dan sebagai proses yaitu bagaimana mendapatkan pengetahuan tersebut. Selain itu, IPA juga dapat pula dipandang sebagai fakta yang menyebabkan sikap dan pandangan yang mitologis menjadi sudut pandang ilmiah.

Berdasarkan uraian tersebut maka yang dimaksud dengan pembelajaran IPA dalam penelitian ini adalah suatu pembelajaran tentang alam. Sehingga dapat mengembangkan pengetahuan, sikap, dan keterampilan siswa.

\subsection{Hasil Belajar IPA di Sekolah Dasar}

Proses belajar mengajar di kelas mempunyai tujuan yang bersifat transaksional, artinya diketahui secara jelas dan operasional oleh guru dan siswa. Tujuan tercapai jika siswa memperoleh hasil belajar seperti yang diharapkan di dalam proses belajar mengajar tersebut. Oleh sebab itu hasil belajar harus dirumuskan dengan baik untuk dapat dievaluasi pada akhir pembelajaran. Belajar adalah aktivitas mental yang berlangsung dalam interaksi anak dengan lingkungan yang menghasilkan perubahan dalam pengetahuan, pemahaman, keterampilan, sikap, dan nilai. Jadi hasil belajar adalah tingkat penguasaan yang dicapai siswa dalam mengikuti program belajar mengajar sesuai dengan tujuan pendidikan yang ditetapkan yang meliputi aspek kognitif, afektif, dan psikomotor.

Hasil belajar menurut Winkel (Bundu, 2004) pada hakekatnya adalah perubahan tingkah laku individu yang relatif menetap sebagai hasil interaktif dengan lingkungan. Hasil belajar IPA tentu saja harus dikaitkan dengan tujuan pendidikan IPA yang telah dicantumkan dalam garis-garis besar program pengajaran IPA di sekolah dengan tidak melupakan hakikat IPA itu sendiri. Oleh sebab itu, pelajaran menggambarkan hasil belajar yang harus dimiliki siswa dan cara siswa memperoleh hasil belajar tersebut.

Hasil belajar IPA di sekolah dasar menurut Sahruddin (2010:29) hendaknya mencakup halhal sebagai berikut: 1) Penguasaan produk ilmiah atau produk IPA yang mengacu pada seberapa besar siswa mengalami perubahan dalam pengetahuan dan pemahaman tentang IPA baik berupa fakta, konsep, prinsip, hukum, maupun teori; 2) Penguasaan proses ilmiah atau proses IPA mengacu pada sejauh mana siswa mengalami perubahan dalam kemampuan proses keilmuan yang terdiri atas keterampilan proses 
IPA; 3) Hasil belajar IPA adalah segenap perubahan tingkah laku yang terjadi pada siswa dalam bidang IPA sebagai hasil mengikuti proses pembelajaran IPA. Hasil belajar biasanya dinyatakan dengan skor yang diperoleh dari tes hasil belajar yang diadakan setelah selesai mengikuti suatu program pembelajaran.

\subsection{Media Audio-Visual (Film Projektor)}

Latuheru (Sahruddin, 2010) mengartikan Media Audio-Visual adalah media pendidikan modern yang sesuai dengan perkembangan zaman (kemajuan ilmu pengetahuan dan teknologi), meliputi media yang dapat dilihat dan didengar secara langsung. Media Audio-Visual merupakan media yang mempunyai unsur suara dan unsur gambar, seperti TV, Film Projector yang menggunakan Komputer, LCD, dan Speaker (Sound System), serta yang lainnya. Jenis media ini mempunyai kemampuan yang lebih baik karena meliputi kedua jenis media yang pertama dan yang kedua. Dari beberapa jenis media Audio-Visual yang telah disebutkan di atas maka yang akan menjadi fokus pembahasan dan sekaligus menjadi objek kajian dalam penelitian ini yaitu media pembelajaran Audio-Visual (Film Projector).

Telah dikemukakan di atas bahwa Film Projector adalah salah satu jenis media AudioVisual yang biasanya ditampilkan melalui bantuan komputer dan media proyeksi seperti LCD yang berfungsi untuk menampilkan film (Visual) pada layar serta Speaker (Sound System) sebagai pelempar suara (Audio).

Tidak ada satupun media yang paling unggul untuk semua tujuan pembelajaran (Degeng dalam sahruddin, 2010:16), pendapat ini memberikan gambaran kepada kita bahwa memang tidak ada satupun media pembelajaran yang dapat kita katakan lebih unggul dari media yang lain. Semua media pembelajaran pasti mempunyai kelebihan dan kekurangan masing-masing. Begitupun Film Projector sebagai salah bagian dari media pembelajaran juga memiliki beberapa kelebihan-kelebihan dan kekurangankekurangan.

Kelebihan Film Projector sebagai media pembelajaran menurut Nasution (2008:104), antara lain :

a) Film sangat baik menjelaskan suatu proses, bila perlu dengan menggunakan "slow motion". b) Tiap siswa dapat belajar sesuatu dari film, yang pandai maupun yang kurang pandai.

c) Film sejarah dapat menggambarkan peristiwa-peristiwa masa lalu secara realistis dalam waktu yang singkat.

d) Film dapat membawa anak dari Negara yang satu ke Negara yang lain dari masa yang satu ke masa yang lain.

e) Film dapat diulangi bila perlu untuk menambah kejelasan.

Sekalipun banyak kelebihannya, Film Projector memiliki kelemahan antara lain harga/biaya produksi relatif mahal, film tidak dapat mencapai semua tujuan pembelajaran, penggunaannya perlu ruang tertutup (gelap/remang-remang).

\section{METODE PENELITIAN}

Subjek penelitian tindakan kelas ini adalah siswa SD Negeri Kompleks IKIP 1 Makassar, Kecamatan Rappocini, Kelas IV-B berjumlah 45 orang. Mata Pelajaran yang diajarkan adalah Ilmu Pengetahuan Alam. Penelitian ini dilakukan pada kurun waktu tiga bulan, Juli-September 2015.

Data yang dikumpulkan melalui catatan observasi dan hasil evaluasi yang dilakukan sejak awal penelitian sampai dengan siklus kedua. Catatan observasi dipergunakan untuk mengetahui peningkatan aktivitas belajar siswa sedangkan evaluasi dilakukan untuk mengukur peningkatan prestasi belajar siswa.

Pada bagian refleksi dilakukan analisis data mengenai proses, masalah dan hambatan yang dijumpai, kemudian dilanjutkan dengan refleksi dampak pelaksanaan tindakan yang dilaksanakan. Salah satu aspek penting dari kegiatan refleksi adalah evaluasi terhadap keberhasilan dan pencapaian tujuan.

Data hasil obervasi pembelajaran dianalisis kemudian ditafsirkan berdasarkan kajian pustaka dan pengalaman guru. Sedangkan hasil belajar siswa berupa hasil tes yang dilakukan pada setiap akhir pembelajaran di siklus pertama dan siklus kedua.

Penelitian Tindakan Kelas ini dilakukan dalam dua siklus, dalam setiap siklus pelaksanaannya mengikuti yang terdiri atas empat langkah, yaitu perencanaan, tindakan, observasi, dan refleksi. 


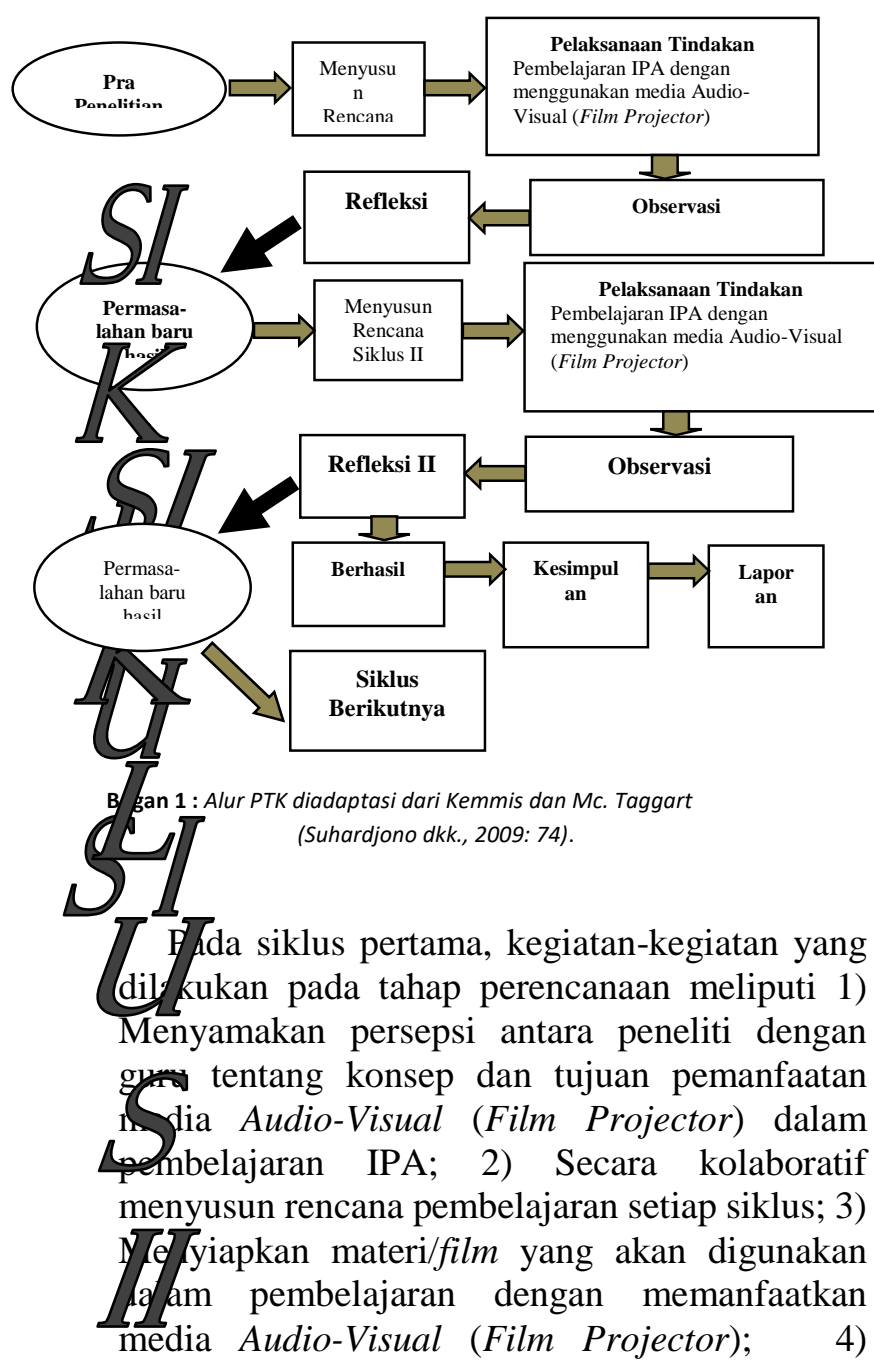

Menyusun rambu-rambu instrumen data keberhasilan guru maupun instrumen data kemajuan hasil dan aktivitas belajar, berupa format observasi, pedoman, wawancara, dan persiapan rekaman kegiatan tindakan berupa video ataupun rekaman foto pelaksanaan tindakan; 5) Peneliti dan guru mengadakan latihan bersama bagaimana mengimplementasikan rencana pembelajaran setiap siklus sebelum dilaksanakannya tindakan.

Pada tahap pelaksanaan, kegiatan yang dilakukan antara lain 1) Tahap Persiapan pembelajaran dengan memanfaatkan media Audio-Visual (Film Projector); 2) Tahap pelaksanaan pembelajaran dengan memanfaatkan media Audio-Visual (Film Projector); 3) Tahap akhir pelaksanaan pembelajaran dengan memanfaatkan media Audio-Visual (Film Projector).

Pada tahap observasi, kegiatan yang dilakukan adalah mengamati seluruh proses tindakan dan pada saat selesai tindakan. Fokus observasi adalah aktivitas guru, siswa dan pemanfaatan media pembelajaran. Aktivitas guru dapat diamati mulai dari awal pembelajaran, saat pembelajaran, dan akhir pembelajaran, pengamatan aktivitas siswa yaitu bagaimana minat dan aktivitas siswa dalam pembelajaran IPA berlangsung, sedangkan pengamatan pemanfaatan media yaitu dengan melihat kesesuaian dengan prinsip pemilihan media dan tata cara penggunaan media pembelajaran.

Pada tahap refleksi, yang dilakukan adalah melakukan refleksi untuk menentukan tindakan pada siklus berikutnya. Jika hasil yang dicapai pada siklus 1 belum sesuai indikator dan target (80\% keatas) sesuai rencana, maka akan direfleksikan bersama tim tentang alternatif pemecahannya dan selanjutnya direncanakan tindakan berikutnya.

Pada siklus kedua, tahap perencanaan dilakukan dengan kegiatan 1) Peneliti menyusun rencana pembelajaran IPA dengan pemanfaatan media Audio-Visual (Film Projector) untuk siklus tindakan kedua; 2) Menyusun bentuk pembelajaran IPA dengan memanfaatkan media Audio-Visual (Film Projector) berdasarkan hasil refleksi dan sesuai dengan substansi materi yang direncanakan pada pembelajaran siklus kedua; 3) Melaksanakan pembelajaran IPA dengan memanfaatkan media Audio-Visual (Film Projector); 4) Melakukan observasi pemanfaatan media Audio-Visual (Film Projector) saat pembelajaran berlangsung; 5) Melakukan diskusi balikan (refleksi) untuk mencari kelemahan yang dilakukan selama pembelajaran pada siklus kedua berlangsung untuk menentukan tindakan pada siklus berikutnya ataukah berhenti pada siklus kedua karena penelitian telah disimpulkan berhasil.

\section{PEMBAHASAN}

\subsection{Deskripsi Kondisi Awal}

Sebelum melaksanakan penelitian, peneliti terlebih dahulu melaksanakan tindakan prapenelitian diantaranya 1) Mengadakan konsultasi dengan Kepala Sekolah dalam hal pelaksanaan penelitian; 2) Melakukan diskusi dengan pihak guru kelas IV-B untuk mendapatkan gambaran bagaimana pelaksanaan pembelajaran IPA dengan memanfaatkan media Audio-Visual (Film Projector); 3) Mengadakan observasi awal terhadap pelaksanaan pembelajaran IPA dengan memanfaatkan media Audio-Visual (Film Projector) dikelas agar dapat memahami karakteristik pembelajaran serta gambaran pelaksanaan pembelajaran IPA di 
kelas sebagai langkah awal yang akan digunakan dalam pelaksanaan tindakan.

Adapun hasil observasi saat pra peneltian terungkap bahwa: 1) guru dalam proses pembelajarannya masih bersifat konvensional atau ceramah saja, 2) guru dalam menyampaikan materi pelajaran kurang dalam menggunakan media pembelajaran yang inovatif sehingga banyak materi pelajaran hanya sebatas konsep dan hafalan saja, 3) guru kurang bervariasi dalam menggunakan media pembelajaran, guru hanya menggunakan metode ceramah dan pendekatan yang diterapkan adalah pendekatan konsep. Sedangkan pada siswa di temukan : siswa kurang menguasai konsep IPA khususnya pada pokok bahasan susunan tubuh manusia, 2) hasil belajar IPA siswa rendah. Hal ini terungkap berdasarkan data hasil observasi yang dilakukan penulis kepada guru dan siswa selama pembelajaran IPA berlangsung.

Selain melakukan observasi, penulis juga meminta data awal hasil belajar IPA dari guru kelas untuk mengetahui sejauh mana hasil belajar dan pemahaman siswa terhadap materi. Dari data awal tersebut terungkap bahwa hasil belajar IPA siswa kelas IV-B rendah. Adapun data awal hasil belajar IPA siswa dapat dilihat pada tabel:

Table 2 : Data Awal Hasil Belajar Siswa Pra Penelitian

\begin{tabular}{cccccc}
\hline No & Interval & F & $\mathbf{( \% )}$ & Kategori & Rerata \\
\hline $\mathbf{1}$ & $0-59$ & 12 & 26,67 & Sangat Rendah & \\
$\mathbf{2}$ & $60-69$ & 12 & 26,67 & Rendah & \\
$\mathbf{3}$ & $70-79$ & 8 & 17,78 & Sedang & 66,38 \\
$\mathbf{4}$ & $80-89$ & 13 & 28,89 & Baik & \\
$\mathbf{5}$ & $90-100$ & 0 & 0 & Sangat Baik & \\
\hline & Jumlah & 45 & 100 & & \\
\hline
\end{tabular}

Dari tabel diatas menunjukkan bahwa, yang memperoleh nilai 90-100 dengan kategori sangat baik sebanyak $0 \%$, yang memperoleh nilai 80-89 dengan kategori baik sebanyak 13 siswa atau $28,89 \%$, yang memperoleh nilai 70-79 dengan kategori sedang adalah 8 orang siswa atau $17,78 \%$, yang memperoleh nilai 60-69 dengan kategori rendah sebanyak 12 orang siswa atau 26,67\% dan yang memperoleh nilai 0-59 dengan kategori sangat rendah sebanyak 12 orang siswa atau $26,67 \%$.

Berdasarkan hasil observasi dan data awal hasil belajar IPA siswa diatas maka peneliti bersama guru kelas IV-B atas persetujuan Kepala SD Negeri Kompleks IKIP 1 Makassar sepakat untuk melaksanakan tindakan perbaikan melalui Penelitian Tindakan Kelas pada Siklus I.

\subsection{Deskripsi Hasil Tindakan Siklus Pertama 4.2.1 Perencanaan}

Setelah ditetapkan untuk memanfaatkan media Audio-Visual (Film Projector) dalam pembelajaran IPA, maka kegiatan selanjutnya adalah menyiapkan beberapa hal yang diperlukan saat pelaksanaan pembelajaran. Setelah melakukan konsultasi dengan kepala SD Negeri Kompleks IKIP 1, dan teman sejawat, peneliti melakukan hal-hal seperti 1) Menyamakan persepsi antara peneliti dengan guru tentang konsep dan tujuan pemanfaatan media AudioVisual (Film Projector) dalam pembelajaran IPA; 2) Secara kolaboratif menyusun rencana pembelajaran untuk tindakan Siklus I; 3) Menyiapkan materi/film yang akan digunakan dalam pembelajaran dengan memanfaatkan media Audio-Visual (Film Projector); 4) Menyusun rambu-rambu instrumen data keberhasilan guru maupun instrumen data kemajuan hasil dan aktivitas belajar, berupa format observasi, tes, dan persiapan rekaman kegiatan tindakan berupa video ataupun rekaman foto pelaksanaan tindakan; 5) Peneliti dan teman sejawat mengadakan latihan bersama bagaimana mengimplementasikan rencana pembelajaran pada Siklus I sebelum dilaksanakannya tindakan.

\subsubsection{Pelaksanaan Tindakan}

Pelaksanaan tindakan Siklus I dilaksanakan pada hari Selasa tanggal 21 Juli 2015. Adapun kegiatan guru dalam melaksanakan tindakan pembelajaran IPA dengan memanfaatkan media Audio-Visual (Film Projector) adalah di Kegiatan awal, pembelajaran dengan memanfaatkan media Audio-Visual (Film Projector), yaitu : memberi salam, melakukan persiapan kegiatan belajar mengajar, melakukan pengelolaan kelas, mendata kehadiran siswa serta berdoa bersama, menyampaikan apersepsi, menyampaikan tujuan 
pembelajaran, menata posisi media yang digunakan agar semua siswa dapat mengamati dengan jelas, mengatur dan menata posisi tempat duduk siswa agar memungkinkan siswa dapat mengamati dengan jelas apa yang ditampilkan;

Kegiatan inti, pembelajaran dengan memanfaatkan media Audio-Visual (Film Projector), yaitu : a) Guru memperlihatkan kepada siswa gambar serta menjelaskan bagianbagiannya; b) Guru menampilkan Film yang berisi materi IPA melalui Komputer dan LCD sebagai media proyeksi film pada layar serta Speaker (Sound System) sebagai alat pelempar suara (audio) berisi penjelasan materi dalam Film; c) Siswa mengamati materi yang ditampilkan oleh media Audio-Visual (Film Projector) secara individu maupun kelompok; d) Guru mengamati jalannya proses pembelajaran; e) Guru dan siswa bertanya jawab tentang materi yang ditampilkan dalam Film; f) Siswa secara bergantian mengemukakan isi materi dalam film; g) Guru mengevaluasi proses pembelajaran yang telah dilakukan. Kegiatan akhir, pelaksanaan pembelajaran dengan memanfaatkan media Audio-Visual (Film Projector), yaitu menyimpulkan hasil pembelajaran dan menutup pelajaran.

Setelah diadakan proses pembelajaran pada Siklus I, untuk mengetahui sejauh mana peningkatan hasil belajar IPA siswa diberikan tes diakhir pembelajaran. Soal yang diberikan pada Siklus I ini terdiri dari 8 butir soal. Adapun data kemampuan siswa dalam menjawab pertanyaan yang diberikan peneliti diakhir pembelajaran pada Siklus I, dapat dilihat pada tabel berikut :

Table 3 : Data Hasil Belajar pada Siklus I

\begin{tabular}{cccccc}
\hline No & Interval & $\mathbf{F}$ & $\mathbf{( \% )}$ & Kategori & Rerata \\
\hline $\mathbf{1}$ & $0-59$ & 9 & 20 & Sangat & \\
$\mathbf{2}$ & $60-69$ & 10 & 22,22 & Rendah & \\
$\mathbf{3}$ & $70-79$ & 13 & 28,89 & Rendah & \\
$\mathbf{4}$ & $80-89$ & 12 & 26,67 & Sedang & 69,93 \\
$\mathbf{5}$ & $90-$ & 1 & 2,22 & Baik & \\
& 100 & & & Bangat & \\
\hline Jumlah & 45 & 100 & & \\
\hline
\end{tabular}

Dari tabel diatas menunjukkan bahwa, yang memperoleh nilai 90-100 dengan kategori sangat baik sebanyak 1 orang siswa atau 2,22\%, yang memperoleh nilai 80-89 dengan kategori baik sebanyak 12 siswa atau 26,67\%, yang memperoleh nilai 70-79 dengan kategori sedang adalah 13 orang siswa atau $28,89 \%$, yang memperoleh nilai 60-69 dengan kategori rendah sebanyak 10 orang siswa atau $22,22 \%$ dan yang memperoleh nilai 0-59 dengan kategori sangat rendah sebanyak 9 orang siswa atau 20,00\%.

\subsubsection{Observasi}

Hal-hal yang diobservasi pada pelaksanaan tindakan Siklus I adalah melihat apakah pelaksanaan pembelajaran IPA dengan memanfaatkan media Audio-Visual (Film Projector) ini sudah sesuai dengan Rencana Pelaksanaan Pembelajaran yang telah dibuat, apakah telah sesuai dengan prinsip-prinsip pemilihan media pembelajaran, serta melihat aktivitas guru dan siswa dalam pembelajaran.

Adapun hasil observasi terhadap siswa menunjukkan hal-hal seperti 1) Siswa telah menyimak film yang ditampilkan namun kondisi ruang yang sangat luas dan adanya gangguan dari siswa lain dari luar kelas membuat siswa belum bisa fokus dalam belajar karena; 2) Beberapa siswa tidak mencatat hal-hal penting dari film yang ditampilkan; 3) Beberapa siswa masih malu-malu untuk bertanya dan mengungkapkan pendapatnya; 4) Belum semua siswa mampu menjawab tes hasil belajar dengan baik yang diberikan peneliti diakhir pembelajaran.

Sedangkan hasil observasi terhadap peneliti yang diamati oleh teman sejawat sebagai observer menunjukkan hal-hal seperti 1) Peneliti tidak menyampaikan tujuan pembelajaran; 2) Pemberian motivasi belajar terhadap siswa masih kurang sehingga ada sebagian siswa tidak memperhatikan penjelasan peneliti tentang materi IPA; 3) Penataan ruangan yang dilakukan peneliti masih kurang seimbang antara jumlah siswa yang sedikit dengan ruangan kelas yang besar;4) Peneliti masih kurang dalam membangkitkan keberanian siswa untuk bertanya dan mengungkapkan pendapat; 4) Guru kurang mampu menguasai kelas diakibatkan adanya gangguan dari luar kelas; 5) Peneliti masih kurang dalam membimbing siswa yang mengalami kesulitan dalam belajar.

\subsubsection{Refleksi}

Menurut pengamatan teman sejawat, peneliti pada saat memulai pelajaran tidak mengungkapkan tujuan pembelajaran sehingga siswa kurang terarah dalam belajar, masih kurang memotivasi siswa agar semangat belajar, adanya gangguan dari luar kelas yang menyebabkan siswa kurang fokus dalam belajar.

Demikian pula dari aspek siswa, tidak semua siswa fokus menyimak isi film tersebut dikarenakan beberapa siswa masih terfokus pada media yang digunakan bukan pada materi pelajaran karena media Audio-Visual (Film 
Projector) ditambah lagi adanya gangguan dari luar kelas yaitu adanya siswa dari kelas lain yang menyaksikan pembelajaran dari luar kelas melalui jendela kelas. Selain itu masih ada beberapa siswa yang enggan bertanya dan mengemukakan pendapatnya.

Adapun kegagalan dan keberhasilan dari Siklus I ini adalah 1) Penyajian pada tahap persiapan, pelaksanaan dan tahap akhir dalam pembelajaran IPA dengan menggunakan media Audio-Visual (Film Projector) berjalan sebagaimana yang telah direncanakan. Namun pada saat tahap persiapan, dan tahap akhir/tindak lanjut pembelajaran masih terdapat kekurangankekurangan, olehnya itu pada tahap persiapan dan tahap akhir pembelajaran perlu ditingkatkan; 2) Siswa merasa senang belajar IPA dengan menggunakan media Audio-Visual (Film Projector), karena siswa dapat melihat dan mendengarkan secara langsung materi dengan menggunakan alat yang sama sekali belum pernah mereka lihat sebelumnya; 3) Penggunaan media Audio-Visual (Film Projector) sebagai media dalam pembelajaran sangat menarik perhatian dan minat siswa dalam belajar, selain itu penggunaan media tersebut juga memudahkan siswa cepat memahami materi dalam film tersebut; 4) Pada saat siswa diminta untuk menyimak materi yang disajikan didepan kelas, siswa mengalami kesulitan karena awalnya materi yang ditampilkan oleh media AudioVisual (Film Projector), ditampilkan terlalu tinggi sehingga siswa agak terlalu menengok keatas. Namun berkat bimbingan dan antisipasi yang dilakukan guru hal tersebut dapat diatasi, sehingga siswa dapat menyimak dengan baik; 5) Hasil tes hasil belajar untuk mengetahui peningkatan hasil belajar IPA belum mencapai target ketuntasan belajar.; 6) Setelah dilakukan diskusi, seluruh siswa beranggapan bahwa mereka sangat senang dan tertarik mengikuti pelajaran IPA yang diberikan guru dengan menggunakan media Audio-Visual (Film Projector).

Berdasarkan hasil observasi dan evaluasi pada Siklus I belum mencapai target Indikator Keberhasilan Penelitian yang telah ditetapkan oleh peneliti merujuk pada pendapat Nurkancana (Sahruddin, 2010) yakni $80 \%$ siswa harus memperoleh nilai $\geq 70$. Hal ini dapat dilihat dari pelaksanaan tindakan Siklus I yang masih jauh dari yang diharapkan yaitu hanya 58\% atau 26 orang siswa saja yang memperoleh nilai $\geq 70$ dengan rerata 69,93 maka penelitian dilanjutkan pada Siklus II.

\subsection{Deskripsi Hasil Tindakan Siklus Kedua 4.3.1 Perencanaan}

Berdasarkan hasil observasi, evaluasi, dan refleksi pelaksanaan tindakan Siklus I belum mencapai target Indikator Keberhasilan Penelitian yang ditentukan oleh peneliti, sehingga peneliti bersama guru dan teman sejawat secara berkolaborasi merencanakan tindakan pada Siklus II. Kelemahan-kelemahan dan kekurangan-kekurangan yang ada pada Siklus I akan diperbaiki pada Siklus II, begitupun keberhasilan-keberhasilan pada Siklus I akan dipertahankan dan dikembangkan di Siklus II.

Hal-hal yang perlu dilakukan dalam rangka memperbaiki kelemahan-kelemahan dan kekurangan dalam Siklus I yaitu 1) Menyampaikan tujuan pembelajaran yang akan dicapai dalam pembelajaran yang akan dilaksanakan, sehingga siswa dapat terarah dalam belajar; 2) Memberikan motivasi kepada seluruh siswa agar mereka lebih aktif dan semangat dalam belajar; 3 3) Mengatur waktu tindakan pada saat semua siswa masuk kelas agar pembelajaran dapat berjalan dengan baik tanpa ada gangguan dari luar kelas sehingga siswa dapat lebih fokus dalam belajar; 4) Mengoptimalkan pengaturan posisi tempat duduk siswa sehingga semua siswa dapat memperhatikan materi yang ditampilkan melalui media Audio-Visual (Film Projector) dengan baik dan dapat mendengarkan dengan baik penjelasan guru; 5) Memberikan kesempatan seluas-luasnya kepada semua siswa untuk mengemukakan pendapatnya, dan menanyakan semua hal-hal yang belum dipahami selama pembelajaran berlangsung; 6) Peneliti harus membangkitkan keberanian dan minat siswa dalam mengungkapkan pendapatnya dan menanyakan hal-hal yang kurang dimengerti sehubungan dengan materi pelajaran; 7) Lebih intensif membimbing siswa yang masih mengalami kesulitan dalam belajar. 8) Peneliti harus tegas menegur siswa yang kurang memperhatikan pelajaran agar diakhir pembelajaran siswa dapat mengerjakan tes dan menjawab soal dengan baik.

\subsubsection{Pelaksanaan Tindakan}

Pelaksanaan tindakan Siklus II dilaksanakan pada hari Selasa tanggal 8 September 2015. Adapun kegiatan guru dalam melaksanakan tindakan pembelajaran IPA dengan 
memanfaatkan media Audio-Visual (Film Projector) adalah di Kegiatan awal pembelajaran dengan memanfaatkan media Audio-Visual (Film Projector), yaitu : memberi salam, melakukan persiapan kegiatan belajar mengajar, melakukan pengelolaan kelas, mendata kehadiran siswa serta berdoa bersama, menyampaikan apersepsi, menyampaikan tujuan pembelajaran, memotivasi siswa agar semangat dan serius dalam belajar, menata posisi media Audio-Visual yang digunakan agar semua siswa dapat mengamati dengan jelas, mengatur dan menata posisi tempat duduk siswa agar memungkinkan siswa dapat mengamati dengan jelas apa yang ditampilkan.

Kegiatan inti pembelajaran dengan memanfaatkan media Audio-Visual (Film Projector), yaitu : 1) Guru memperlihatkan kepada siswa gambar serta menjelaskan bagianbagiannya; 2) Guru menampilkan Film yang berisi materi IPA melalui Komputer dan LCD sebagai media proyeksi film pada layar serta Speaker (Sound System) sebagai alat pelempar suara (audio) berisi penjelasan materi dalam Film; 3) Siswa mengamati materi yang ditampilkan oleh media Audio-Visual (Film Projector) secara individu maupun kelompok; 4) Guru mengamati jalannya proses pembelajaran; 5) Guru dan siswa bertanya jawab tentang materi yang ditampilkan dalam Film; 6) Siswa secara bergantian mengemukakan isi materi dalam film; g) Guru mengevaluasi proses pembelajaran yang telah dilakukan. Kegiatan akhir pelaksanaan pembelajaran dengan memanfaatkan media Audio-Visual (Film Projector), yaitu menyimpulkan hasil pembelajaran dan menutup pelajaran.

Setelah diadakan proses pembelajaran pada Siklus II, untuk mengetahui sejauh mana peningkatan hasil belajar IPA siswa diberikan tes diakhir pembelajaran. Soal yang diberikan pada Siklus II terdiri dari 8 butir soal. Adapun data kemampuan siswa dalam menjawab pertanyaan yang diberikan peneliti diakhir pembelajaran pada Siklus II, dapat dilihat pada tabel :

Table 4 : Data Hasil Evaluasi Siklus II

\begin{tabular}{cccccc}
\hline No & Interval & $\mathbf{F}$ & $\mathbf{( \% )}$ & Kategori & Rerata \\
\hline $\mathbf{1}$ & $0-59$ & 0 & 0 & Sangat Rendah & \\
$\mathbf{2}$ & $60-69$ & 4 & 8,89 & Rendah & \\
$\mathbf{3}$ & $70-79$ & 19 & 42,22 & Sedang & 81,84 \\
$\mathbf{4}$ & $80-89$ & 8 & 17,78 & Baik & \\
$\mathbf{5}$ & $90-100$ & 14 & 31,11 & Sangat Baik & \\
\hline Jumlah & 45 & 100 & & \\
\hline
\end{tabular}

Dari tabel diatas menunjukkan bahwa, yang memperoleh nilai 90-100 dengan kategori sangat baik sebanyak 14 orang siswa atau $31,11 \%$, yang memperoleh nilai 80-89 dengan kategori baik sebanyak 8 siswa atau $17,78 \%$, yang memperoleh nilai 70-79 dengan kategori sedang adalah 19 orang siswa atau $42,22 \%$, yang memperoleh nilai 60-69 dengan kategori rendah sebanyak 4 orang siswa atau $8,89 \%$ dan yang memperoleh nilai 0 59 dengan kategori sangat rendah sebanyak 0 orang siswa atau $0 \%$.

\subsubsection{Observasi}

Pada pelaksanaan tindakan pada Siklus II secara umum hasil observasi dan evaluasi terjadi peningkatan dibandingkan dengan Siklus I. Hal ini terlihat pada hasil observasi peneliti dan siswa.

Hasil observasi terhadap peneliti menunjukkan bahwa 1) Peneliti sudah menjelaskan tujuan pembelajaran dan memotivasi siswa; 2) Peneliti sudah memilih ruangan yang tepat untuk melaksanakan pembelajaran dengan memanfaatkan media Audio-Visual (Film Projector) dalam pembelajaran; 3) Peneliti telah melakukan pengaturan posisi tempat duduk siswa sehingga mereka dapat mengikuti pembelajaran dengan baik; 4) Peneliti menggunakan alat peraga penunjang pembelajaran; 5) Peneliti sudah memberikan kesempatan seluas-luasnya kepada siswa untuk mengungkapkan pendapat dan menanyakan hal-hal yang masih kurang dipahami selama pembelajaran; 6) Peneliti sudah membimbing siswa yang mengalami kesulitan dalam mengerjakan tugas yang diberikan.

Hasil observasi terhadap siswa menunjukkan 1) Siswa sudah memperhatikan penjelasan peneliti dengan baik saat proses pembelajaran berlangsung; 2) Siswa sudah fokus dan bersemangat dalam belajar karena tidak lagi terganggu oleh gangguan dari luar kelas; 3) Siswa sudah berani menanyakan hal-hal yang kurang jelas yang ada kaitannya dengan materi yang dipelajari; 4) Berkat motivasi yang diberikan oleh guru sebagian besar siswa telah semangat dalam belajar; 5) Melalui bimbingan guru sebagian besar siswa sudah mampu mengerjakan tugas dengan baik.

\subsubsection{Refleksi}

Menurut pengamatan teman sejawat, peneliti pada saat memulai pelajaran telah mengungkapkan tujuan pembelajaran sehingga siswa lebih terarah dalam belajar, telah memotivasi siswa untuk lebih semangat dalam belajar, dan juga telah berusaha menciptakan 
suasana pembelajaran yang bebas dari gangguan dari luar kelas serta telah berusaha melakukan penataan kelas dengan baik, peneliti sudah menciptakan suasana pembelajaran yang menyenangkan dan menggunakan alat peraga yang menunjang jalannya pembelajaran.

Demikian pula dari aspek siswa, semua siswa telah fokus dalam menyimak isi film tersebut siswa antusias untuk bertanya dan mengemukakan pendapatnya dan juga siswa sudah mampu menjawab dengan baik tes hasil belajar yang diberikan.

Adapun kegagalan dan keberhasilan dari Siklus II ini adalah 1) Penyajian pada tahap persiapan, pelaksanaan dan tahap akhir dalam pembelajaran IPA dengan menggunakan media Audio-Visual berjalan sebagaimana yang telah direncanakan; 2) Siswa merasa senang belajar IPA dengan menggunakan media Audio-Visual, karena siswa dapat melihat dan mendengarkan secara langsung materi dengan menggunakan alat yang sama sekali belum pernah mereka lihat sebelumnya; 3) Penggunaan media Audio-Visual sebagai media dalam pembelajaran sangat menarik perhatian dan minat siswa dalam belajar, selain itu penggunaan media tersebut juga memudahkan siswa cepat memahami materi dengan cepat; 4) Hasil tes untuk mengetahui peningkatan hasil belajar IPA telah mencapai target yang peneliti tentukan; 5) Setelah dilakukan diskusi, seluruh siswa beranggapan bahwa mereka sangat senang dan tertarik mengikuti pelajaran IPA yang diberikan guru dengan menggunakan media Audio-Visual (Film Projector).

Berdasarkan hasil observasi dan evaluasi pelaksanaan tindakan Siklus II ini sudah lebih baik dari Siklus I. Hasil observasi dan evaluasi pada pelaksanaan tindakan siklus II ini menunjukkan adanya peningkatan yang signifikan karena proses pembelajaran telah berjalan dengan baik sesuai dengan yang direncanakan, dan hasil belajar IPA siswa juga mengalami peningkatan dan mencapai target Indikator Keberhasilan Penelitian yang peneliti tetapkan merujuk pada pendapat Nurkancana (Sahruddin, 2010) yakni $80 \%$ siswa harus memperoleh nilai $\geq 70$. Hal ini dapat dilihat dari pelaksanaan tindakan Siklus II yang telah mencapai peningkatan dari $58 \%$ atau 19 orang siswa yang memperoleh nilai $\geq 70$ dengan rerata 69,93 pada Siklus I menjadi 91\% atau 41 siswa yang memperoleh nilai $\geq 70$ dengan rerata 81,84 pada Siklus II, maka dengan demikian penelitian tidak dilanjutkan lagi karena telah berhasil.

\section{PEMBAHASAN HASIL PENELITIAN}

Dalam proses pembelajaran Siklus I, tindakan dilaksanakan di dalam ruang belajar kelas IV-B SD Negeri Kompleks IKIP 1 Makassar. Sebelum memulai pembelajaran peneliti terlebih dahulu menyiapkan media Audio-Visual yang akan digunakan. Dalam pembelajaran peneliti menjelaskan terlebih dahulu Materi Pembelajaran yang terdapat pada gambar, setelah itu barulah diputarkan film yang berkaitan dengan materi tersebut. Diakhir pembelajaran Siklus I, siswa diberikan beberapa butir soal oleh peneliti sesuai dengan indikator dan tujuan pembelajaran yang telah direncanakan dalam Rencana Pelaksanaan Pembelajaran. Pembelajaran Siklus I ini pada umumnya berjalan lancar, namun pada kegiatan ini masih terdapat berbagai macam kekurangan-kekurangan. Dimana kekurangan-kekurangan tersebut ada yang berasal dari guru/peneliti dan ada juga yang berasal dari siswa. Kekurangan dari aspek guru diantaranya pada awal pembelajaran guru tidak menyampaikan tujuan pembelajaran, peneliti kurang memberikan motivasi kepada siswa, dan pemilihan ruangan belajar dengan memanfaatkan media Audio-Visual yang kurang tepat sehingga terjadi gangguan pembelajaran dari luar kelas.

Sedangkan kekurangan dari aspek siswa yaitu pada saat proses pembelajaran berlangsung siswa kurang fokus diakibatkan adanya gangguan dari luar kelas yang menyaksikan jalannya pembelajaran, masih banyak siswa yang ragu untuk mengungkapkan pendapatnya dan menanyakan hal-hal yang masih kurang dipahami sehingga peneliti kesulitan dalam mengetahui dimana letak kelemahan siswa dalam pembelajaran.

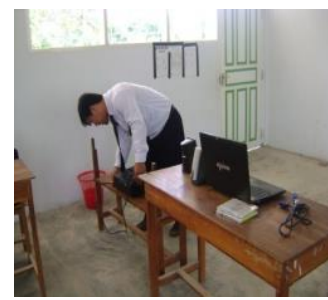

Memasang Media

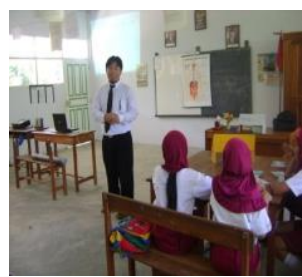

Membuka Pelajaran
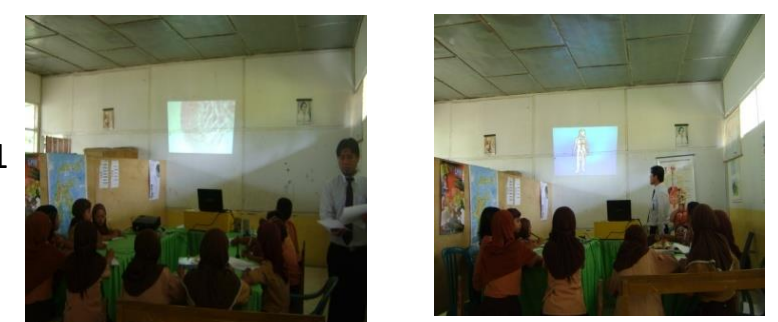


\section{Membagikan LKS Materi}

Berdasarkan hasil observasi dan evaluasi yang dilaksanakan diakhir tindakan Siklus I, terlihat adanya peningkatan hasil belajar IPA yaitu $58 \%$ atau 29 orang siswa yang memperoleh nilai $\geq 70$ dengan rerata 69.93 dibandingkan dengan data awal yang diperoleh yaitu hanya $47 \%$ atau 21 orang siswa saja yang memperoleh nilai $\geq 70$ dengan rerata 66,38. Melihat kekurangan-kekurangan yang masih ada serta pencapaian hasil belajar IPA pada Siklus I belum memenuhi standar Indikator Keberhasilan Penelitian yang ditetapkan peneliti yaitu $80 \%$ siswa harus memperoleh nilai $\geq 70$, maka penelitian dilaksanakan pada Siklus II.

Pada Siklus II, pembelajaran IPA dengan memanfaatkan media Audio-Visual (Film Projector) dalam pembelajaran IPA kembali dilaksanakan. Sebelum memulai pembelajaran peneliti terlebih dahulu menyiapkan media Audio-Visual yang akan digunakan dan beberapa alat peraga penunjang pembelajaran seperti patung manusia tampak luar dalam dan beberapa gambar yang berisi gambar materi pelajaran. Dalam pembelajaran peneliti menjelaskan terlebih dahulu materi yang terdapat pada gambar, setelah itu barulah diputarkan film yang berkaitan dengan materi tersebut. Diakhir pembelajaran Siklus II, siswa kembali diberikan beberapa butir soal oleh peneliti sesuai dengan indikator dan tujuan pembelajaran yang telah direncanakan dalam Rencana Pelaksanaan Pembelajaran.
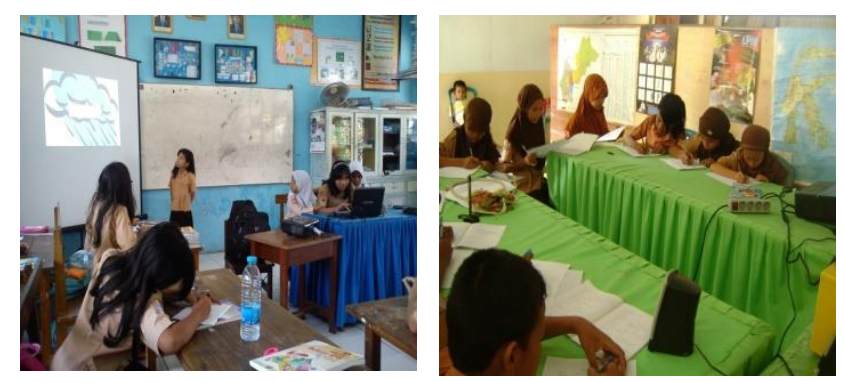

\section{Presentase Kelompok Tahap Evaluasi} Sumber : Dok. Alphian, 2015

Berdasarkan hasil observasi pada tindakan Siklus II, kegiatan peneliti dan siswa meningkat, dimana kekurangan-kekurangan yang terjadi pada Siklus I sudah dapat diperbaiki pada Siklus II. Peneliti sudah mampu menggunakan waktu secara efisien sehingga semua kegiatan yang telah direncanakan dapat dilaksanakan. Siswa lebih memperhatikan penjelasan peneliti maupun materi yang ditampilkan dalam film dan sudah berani mengungkapkan pendapat dan menanyakan hal-hal yang masih kurang dipahami sehubungan dengan materi.

Berdasarkan hasil evaluasi yang dilaksanakan diakhir tindakan Siklus II, terlihat adanya peningkatan hasil belajar IPA yaitu $91 \%$ atau 41 orang siswa yang memperoleh nilai $\geq 70$ dengan rerata 81,84 dibandingkan dengan hasil belajar IPA yang diperoleh pada Siklus I yaitu hanya $58 \%$ atau 26 orang siswa yang memperoleh nilai $\geq 70$ dengan rerata 69,93 , dengan kata lain telah mencapai target Indikator Keberhasilan Penelitian yang ditentukan oleh peneliti yaitu $\geq 80 \%$ memperoleh nilai $\geq 70$.

Kesimpulan dari data yang telah diperoleh pada hasil evaluasi Siklus I, dan Siklus II dapat dilihat pada grafik berikut ini: 
Grafik 1 : Hasil Belajar IPA pada Data Awal, Siklus I dan Siklus II

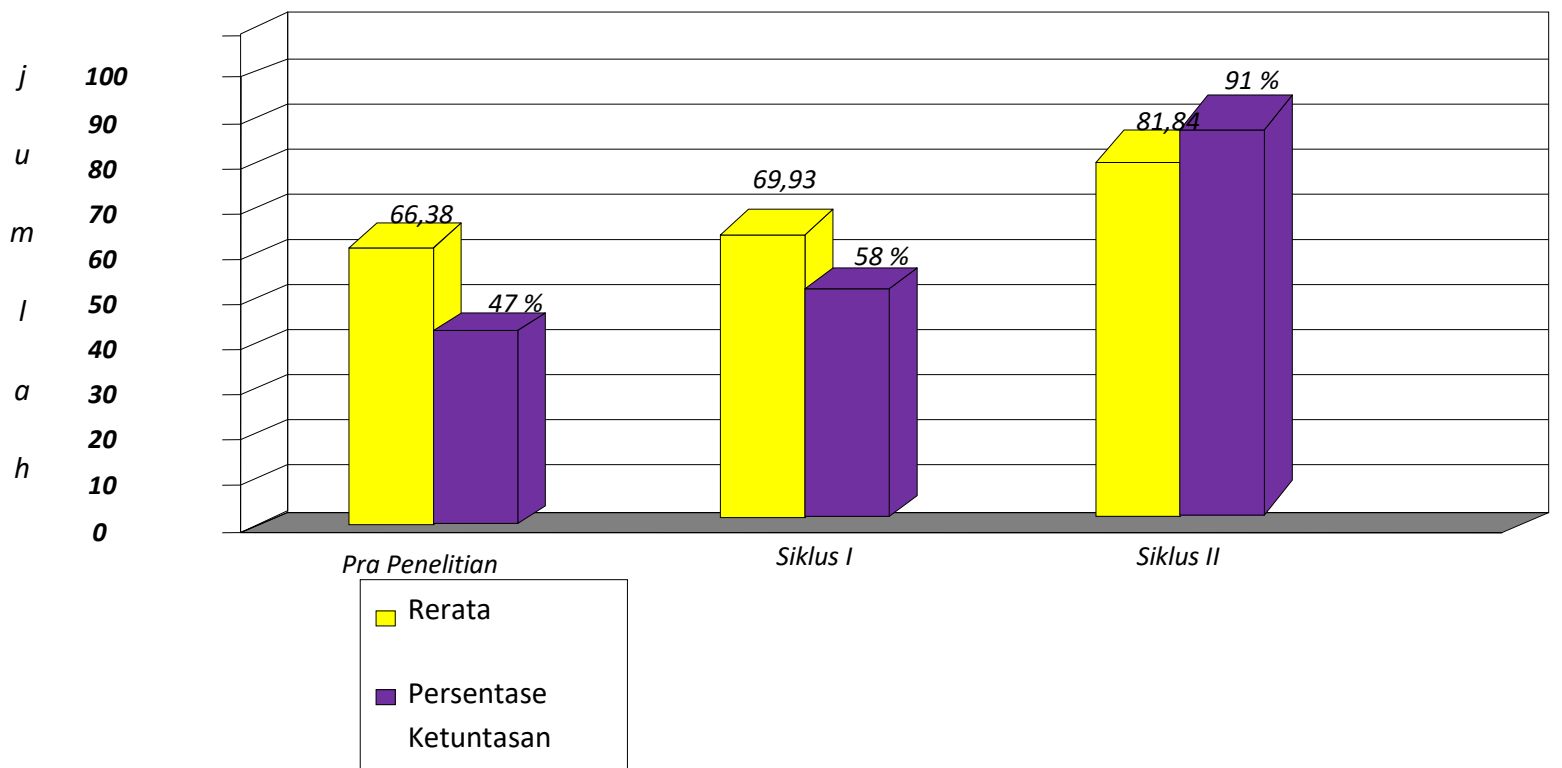

Dari grafik diatas diperoleh kesimpulan tentang hasil belajar IPA siswa kelas VI-B SD Negeri Kompleks IKIP 1 Makassar dengan memanfaatkan media Audio-Visual (Film Projector) menunjukkan bahwa data awal hasil belajar IPA siswa $47 \%$ atau 21 orang anak yang memperoleh nilai $\geq 70$ dengan nilai rerata siswa 66,38, hal ini mengalami peningkatan pada Siklus I yang memperoleh nilai $\geq 70$ yaitu $58 \%$ atau 26 orang siswa dengan rerata siswa 69,93. Selanjutnya pada Siklus II meningkat lagi siswa yang memperoleh nilai $\geq 70$ yaitu $91 \%$ atau 41 orang siswa dengan rerata siswa 81,84.

Indikator Keberhasilan Penelitian yang peneliti tetapkan dalam penelitian ini telah tercapai. Dalam hal ini minimal $80 \%$ siswa telah memperoleh nilai $\geq 70$, maka penelitian ini dihentikan pada Siklus II karena telah dianggap berhasil. Ini berarti hipotesis penelitian telah tercapai yaitu "Jika media Audio-Visual (Film Projector) dimanfaatkan dalam pembelajaran IPA, maka hasil belajar IPA siswa kelas IV-B SD Negeri Kompleks IKIP 1 Makassar akan meningkat".

Berdasarkan hal-hal diatas maka dapat disimpulkan bahwa pemanfaatan media AudioVisual (Film Projector) pada mata pelajaran IPA di SD Negeri Kompleks IKIP 1 Makassar memberikan dampak yang cukup signifikan terhadap peningkatan hasil belajar IPA siswa.

\section{PENUTUP}

Berdasarkan pembahasan hasil penelitian yang telah disajikan di atas, peneliti menyimpulkan bahwa pemanfaatan media Audio-Visual (Film Projektor) ternyata dapat meningkatkan hasil belajar IPA siswa kelas IV-B SD Negeri Kompleks IKIP 1 Makassar. Pembelajaran menggunakan media tersebut dapat membangkitkan rasa senang, tidak membosankan, membuat siswa menemukan sendiri konsep dari materi ajar sesuai tujuan pembelajaran yang ditetapkan karena media tersebut melibatkan seluruh aspek belajar siswa.

Oleh karena itu, peneliti menyarankan agar para guru berupaya meningkatkan hasil belajar IPA siswa dengan berbagai cara yang inovatif dan menyenangkan, salah satunya dengan memanfaatkan media Audio-Visual (Film Projektor).

\section{DAFTAR PUSTAKA}

Arsyad, Azhar. 2009. Media Pembelajaran. Jakarta: PT. RajaGrafindo Persada.

Asnawir dan Usman, M. Basyiruddin. 2002. Media Pembelajaran. Jakarta: Ciputat Pers.

Bundu, Patta. 2004. Penilaian Keterampilan Proses dan Sikap Ilmiah. Jakarta: Depdiknas.

Darmodjo, Hendro. 1992. Pendidikan IPA II. Jakarta: Depdikbud.

Depdiknas. 2003. Media Pembelajaran. Jakarta: Depdiknas 
KTSP. 2006. Mata Pelajaran IPA Untuk Tingkat $S D / M I$. Jakarta : Depdiknas.

Maslichah, Asy"ari. 2006. Penerapan Pendekatan Sains dalam pembelajaran Sains di Sekolah Dasar. Jakarta : Universitas Sanata Dharma Yogyakarta. Nasution. 2008. Teknologi Pendidikan. Jakarta: Bumi Aksara.

RKAS. 2015. Rencana Kerja dan Anggaran Sekolah. Makassar: SD Negeri Kompleks IKIP 1 Makassar.

Sahruddin, Alphian. 2010. Meningkatkan Hasil Belajar IPA Siswa Kelas $V$ melalui Pemanfaatan Multi Media SD Negeri 6 Mojong Kabupaten Sidrap. Makassar: Universitas Negeri Makassar.

Samatowa, Usman. 2006. Membelajarkan IPA di Sekolah Dasar. Jakarta: Departemen Pendidikan nasional.

Slameto. 2003. Belajar dan Faktor-Faktor yang mempengaruhinya. Jakarta: PT. Rineka Cipta.

Suhardjono, d.k.k. 2009. Penelitian Tindakan Kelas. Jakarta: Bumi Aksara.

Trianto. 2007. Model Pembelajaran Terpadu dalam Teori dan Praktek. Jakarta: Prestasi Pustaka Publisher. 